\title{
Çocuk İstismarı Açısından Risk Grubunda Olan Psikiyatrik Engelli Çocukların Engelli Sağlık Kurulu Raporlarına Göre Engel Durumları ve Özel Eğitim Hakkı
}

\author{
Special Education Right and The Disability Features of Psychiatric Disabled Children Who at \\ Risk for Child Abuse
}

\author{
Ahsen Kaya, Orhan Meral, Hülya Güler, Ekin Özgür Aktaş
}

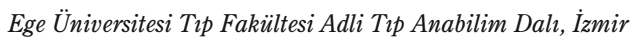

\section{Özet}

Amaç: Engelli çocuklar, çoğunlukla yaptıkları davranışların sonuçlarını tahmin edemediklerinden, davranışlarını yönlendirmekte, iyiyi-kötüden, doğruyu yanlıştan ayırmakta yetersiz kaldıklarından ve kendilerine yönelik eylemlerden kaçınamadıklarından istismar açısından risk grubunu oluşturmaktadırlar. Bu çalışmada, ihmal ve istismar açısından risk grubunda bulunan psikiyatrik engelli çocukların engel sebepleri ve oranlarına dikkat çekmek amaçlandı.

Gereç ve Yöntem: $\mathrm{Bu}$ amaçla, Hastanemiz Engelli Sağlık Kurulu'nda 01.01.2011-30.06.2013 tarihleri arasında düzenlenen 18 yaş altı 2839 çocuk olgunun raporları tarandı ve psikiyatrik engeli bulunan 2103'ünün (\%74) raporu geriye dönük olarak incelendi. Veriler SPSS (versiyon 18.0) istatistik programıla değerlendirildi.

Bulgular: Olguların 1432'si (\%68,1) erkek, 671'i (\%31,9) kız olup, yaş ortalaması $6,7 \pm 4,3$ 'tü. Olgularda tanı olarak en sik $(n=911)$ hafif zeka geriliği mevcuttu. Raporlarda başvuru nedeni olarak özel eğitim alabilmek $(\% 95,3)$ ilk stradaydı.

Sonuç: Psikiyatrik engelli çocukların yararlanabileceği en önemli sosyal haklardan biri olan özel eğitim hakkı, engelli raporu ile ücretsiz olarak sunulmaktadır. Devletin bu hakkı ücretsiz olarak ihtiyaç sahiplerine tanıması, çocuğun istismardan korunmasında önemli bir adımdır. Ayrıca, Engelli Sağlık Kurulu Raporu başvuru nedenleri arasında ilk sırada özel eğitimin yer alması, ailelerin -bilinçli ya da değil- çocuğu istismardan korumaya katkıda bulunduğunu göstermektedir.

Anahtar kelimeler: Çocuk, Engellilik, İhmal, İstismar, Özel eğitim, Zeka geriliği.

\begin{abstract}
Objective: Disabled children are a risky group for child abuse, while they mostly cannot predict the outcomes of the results of their behaviors and also they are insufficient in directing their behaviors, and cannot sift and know right from wrong. In this study, it was aimed to draw attention to the causes of disability and the disability ratios of the children with psychiatric disabilities who are at risk for child abuse.

Materials and Methods: With this regard, 2839 reports belong to children under 18, those were prepared between 01 January, 2011 and 30 June, 2013 by Disabilities Health Board of the Hospital, were examined and 2103 of them included children with psychiatric disabilities were analyzed retrospectively. Data were evaluated with SPSS (version 18.0) statistical program.

Results: 1432 (68.1\%) of the subjects were male, 671 (31.9\%) were female, and the mean age was $6.7 \pm 4.3$. The most common diagnosis for the subjects $(n=911)$ was mild mental retardation. The first mostly stated cause of application in the reports was to have special education (95.3\%).

Conclusion: Special education right, which is one of the most important social rights for children with psychiatric disabilities, is offered free of charge with his/her disability report. The state providing this right free of charge is an important step towards the protection of the children from abuse. Moreover, special education right being ranked as the first among the reasons for application to Disability Report shows that families are contributing to the protect their children from abuse -intentionally or unintentionally-.

Keywords: Child, Disability, Neglect, Abuse, Special education, Mental retardation.
\end{abstract}

\section{Giriş}

Engelli çocuklar, çoğunlukla yaptıkları davranışların sonuçlarını tahmin edemediklerinden, davranışlarını yönlendirmekte, iyiyi-kötüden, doğruyu yanlıştan ayırmakta yetersiz kaldıklarından ve kendilerine yönelik eylemlerden kaçınamadıklarından istismar açısından risk grubunu oluşturmaktadırlar. Engelli çocukların, şiddet kurbanı oldukları ve çocuk istismarının tüm çeşitleri açısından risk grubunda bulundukları, gerek ulusal ve gerekse uluslararası

Sorumlu Yazar: Orhan Meral

Ege Üniversitesi Tip Fakültesi Adli Tip Anabilim Dalı, İzmir

E-mail: orhanmeral@ymail.com

Geliş: 24.11.2014

Düzeltme: 06.01.2015 pek çok çalışmada belirtilmiştir (1-11). Bazı çalısmalarda, özellikle zihinsel engelli çocukların, diğer engelli çocuklara göre daha yüksek oranda şiddete uğrama riskine sahip olduklarından bahsedilmektedir $(4,7)$.

Ülkemizde ilk olarak 1976 yılında kabul edilen ve sonrasında bazı maddelerinde değişiklik yapılan 2022 sayılı “65 Yaşını Doldurmuş Muhtaç, Güçsüz ve Kimsesiz Türk Vatandaşlarına Aylık Bağlanması Hakkında Kanun” sayesinde, muhtaç olduğu kabul edilen yaşlı ve/veya engelli vatandaşlara maddi olarak yardım edilebilmesi imkânı sağlanmıştır (12). Bu yasaya göre; 18 yaşın altındaki engelli yakınlarının bakımını üstlenen ve muhtaç durumda olduğu kanttlanan kişilere de bakım ilişkisini fiilen gerçekleştirmeleri kaydıyla aylık 
bağlanabilmektedir. Bu yasanın ardından, 2005 yılında kabul edilerek yürürlüğe giren 5378 sayılı "Engelliler Hakkında Kanun"un 15. maddesinde: "Hiçbir gerekçeyle engellilerin eğitim alması engellenemez. Engelli çocuklara, gençlere ve yetişkinlere, özel durumları ve farklılıkları dikkate alınarak, bütünleştirilmiş ortamlarda ve engelli olmayanlarla eşit eğitim imkânı sağlanır” denilmektedir (13). Ülkemizde engelli çocuklar için sunulan hizmetler arasında en önemlisi, engelli sağlık kurulu raporu bulunan çocukların özel eğitim giderlerinin devlet tarafından karşılanmasıdır (14). Sunulan bu çalışmada, ihmal ve istismar açısından risk grubunda bulunan psikiyatrik engelli çocukların engel sebepleri ve oranlarına dikkat çekmek, özel eğitim hakkına vurgu yapmak amaçlandı.

\section{Gereç ve Yöntem}

Ege Üniversitesi Tip Fakültesi Klinik Araştırmalar Etik Kurulu'ndan alınan izin sonrası Ege Üniversitesi Tıp Fakültesi Hastanesi’nin Engelli Sağlık Kurulu'nda 01.01.2011-30.06.2013 tarihleri arasında düzenlenen 18 yaş altı 2839 çocuk olgunun raporları incelendi. Psikiyatrik engeli bulunan 2103’ünün (\%74) raporu çalışma kapsamına alındı. Bu raporlar geriye dönük olarak yaş, cinsiyet, psikiyatrik tanı, başvuru nedenleri, engel durumuna göre tüm vücut fonksiyon kaybı oranları ile psikiyatrik engellerinden aldıkları oranlar açısından incelendi. Elde edilen veriler SPSS (versiyon 18.0) istatistik programiyla değerlendirildi.

Özürlülüik Ölçütü, Sınıflandırması ve Özürlülere Verilecek Sağlık Kurulu Raporları Hakkında Yönetmelik’e göre “zihinsel, ruhsal ve davranışsal bozukluklar” başlı̆̆ı altında yer alan hastalıklar/tanılar psikiyatrik engel durumu olarak değerlendirilmiştir (15). İlgili yönetmelikte “zihinsel, ruhsal ve davranışsal bozukluklar” başlığı altında, zeka işlev bozuklukları (0-6 yaş için bilişsel gelişimde gecikme), şizofreni, şizoaffektif bozukluk, sanrısal bozukluklar, atipik veya başka türlü adlandırılamayan psikozlar, yaygın gelişimsel bozukluklar (asperger sendromu, disintegratif psikoz, rett sendromu, otizim, atipik otizim) ve geçici fonksiyon kaybına neden olan ruhsal hastalıklar (duygudurum bozuklukları, obsesif kompulsif bozukluk, özel öğrenme bozuklukları, dikkat eksikliği ve hiperaktivite bozukluğu, vb) yer almaktadır (15).

\section{Bulgular}

Çalışma kapsamında incelenen 2103 raporda çocukların 671'i $(\% 31,9)$ kız ve 1432'si $(\% 68,1)$ erkekti. Yaş ortalaması $6,7 \pm 4,3$ olup, yaş grubu olarak en yüksek oranı $\% 37,8(n=794)$ ile 5-9 yaş grubu çocuklar oluşturmaktaydı (Grafik 1).

Olgularda psikiyatrik tanılar arasinda en sik (n=911, \%43) hafif zeka geriliği mevcuttu. Sadece tek bir psikiyatrik hastalık tanısı bulunan olgu sayısı $1263(\% 60,1)$ iken, $840(\% 39,9)$ olguda birden fazla psikiyatrik hastalık mevcuttu. Olguların psikiyatrik tanıları ve ilgili yönetmeliğe göre mevcut tanıların engel oranları Tablo 1'de belirtildi.

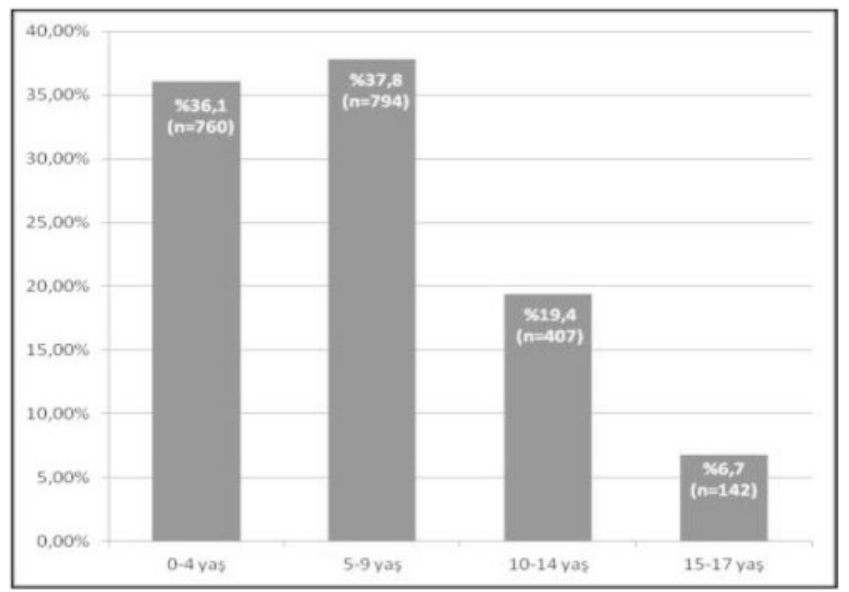

Grafik 1. Olguların yaş gruplarına göre dağılımı.

Tablo 1. Olguların psikiyatrik engel durumları ve ilgili yönetmeliğe göre engel oranları.

\begin{tabular}{|c|c|c|}
\hline Psikiyatrik engel durumlan & $\begin{array}{c}\text { Engel } \\
\text { oranları }\end{array}$ & $\begin{array}{l}\text { Olgu } \\
\text { sayis! }\end{array}$ \\
\hline $\begin{array}{l}\text { Hafif zeka geriliği } \\
\text { (Hafif bilișsel gelișimde gecikme) }\end{array}$ & $\% 50$ & 911 \\
\hline $\begin{array}{l}\text { Orta zeka geriliği } \\
\text { (Orta bilișsel gelișimde gecikme) }\end{array}$ & $\% 70$ & 357 \\
\hline Özel oğrenme bozukluğu & $\begin{array}{l}\text { (Hafif ise } \% 20 \text {, } \\
\text { Ağır ise } \% 30 \text { ) }\end{array}$ & 292 \\
\hline $\begin{array}{l}\text { Ağır zeka geriliği } \\
\text { (Ağır bilișsel gelișimde gecikme) }\end{array}$ & $\% 90$ & 197 \\
\hline $\begin{array}{l}\text { Atipik otizm } \\
\text { (Başka türlü adlandırılamayan yaygın gelişimsel bozukluk) }\end{array}$ & $\% 40$ & 168 \\
\hline Otizm & $\% 80$ & 161 \\
\hline $\begin{array}{l}\text { Dikkat Eksikliği ve Hiperaktivite Bozukluğu } \\
\text { (tedavi edilemeyen) }\end{array}$ & $\% 20$ & 54 \\
\hline Sinırda mental kapasite & $\% 25$ & 41 \\
\hline $\begin{array}{l}\begin{array}{l}\text { Dikkat Eksikliği ve Hiperaktivite Bozukluğu } \\
\text { (tedavi edilebilen) }\end{array} \\
\end{array}$ & 0 & 31 \\
\hline Asperger Sendromu & $\% 40$ & 17 \\
\hline Diğer** & $0-\% 80$ & 11 \\
\hline \multicolumn{2}{|l|}{ Toplam } & $2240^{\prime}$ \\
\hline
\end{tabular}

* Olguların birden fazla hastalık tanısı bulunabildiği için toplam olgu sayısı, çalışmadaki toplam olgu sayısından fazladır.

**Diğer: panik bozukluk, disintegratif bozukluk, depresif bozukluk, bipolar duygudurum bozukluğu, Rett sendromu ve şizofreni tanıları olan 1'er olgu, obsesif kompulsif bozukluk tanılı 2 olgu ile anksiyete bozukluğu tanılı 3 olguyu kapsamaktadır. Adı geçen hastalıkların oranları 0 ile \%80 arasında olup ilgili yönetmelikte ayrı ayrı belirtilmiştir.

Olguların psikiyatrik hastalıkları ve diğer vücut sistemlerini ilgilendiren hastalıkları da (sinir sistemi, kardiyovasküler sistem, görme sistemi, endokrin sistem, onkoloji, kas iskelet sistemi, vs.) göz önünde bulundurularak, Balthazard Formülüne göre hesaplanan ve engelli sağlık 
kurulu raporlarının sonuç kısmında belirtilen engel oranları (tüm vücut fonksiyon kaybı oranları) değerlendirildiğinde; engel oranı ortalaması $\% 59,5 \pm 25,3$ olarak tespit edildi. $\mathrm{Bu}$ oranlar kişinin engelli sağlık kurulu raporu ile faydalanabileceği haklar açısından uygulamada istenen minimum oranlar dikkate alınarak gruplandırıldı̆̆ında, cinsiyete göre dağılımları Tablo 2'de gösterildi.

Tablo 2. Raporların sonuç kısmında belirtilen engel oranlarının cinsiyete göre dağılımı.

\begin{tabular}{|c|c|c|c|c|c|c|}
\hline \multirow{2}{*}{$\begin{array}{l}\text { Kişilerin engel } \\
\text { oranlarn \%'si }\end{array}$} & \multicolumn{2}{|c|}{ Erkek } & \multicolumn{2}{|c|}{ Kız } & \multicolumn{2}{|c|}{ Toplam } \\
\hline & $\mathrm{n}$ & $\%$ * & $\mathrm{n}$ & $\%$ * & n & $\%^{* * *}$ \\
\hline$<40$ & 298 & 75,1 & 99 & 24,9 & 397 & 18,9 \\
\hline $40-49$ & 112 & 81,8 & 25 & 18,2 & 137 & 6,5 \\
\hline $50-59$ & 386 & 68,1 & 181 & 31,9 & 567 & 27,0 \\
\hline $60-79$ & 252 & 64,9 & 136 & 35,1 & 388 & 18,4 \\
\hline $80-89$ & 124 & 58,2 & 89 & 41,8 & 213 & 10,1 \\
\hline$\geq 90$ & 260 & 64,8 & 141 & 35,2 & 401 & 19,1 \\
\hline Toplam & 1432 & 68,1 & 671 & 31,9 & 2103 & 100,0 \\
\hline
\end{tabular}

* Satırda bulunan olgu sayıları göz önünde bulundurularak yüzdeler hesaplanmıştır.

** Sütunda bulunan olgu sayıları göz önünde bulundurularak yüzdeler hesaplanmıştır.

Olguların diğer bölümleri ilgilendiren hastalıklarının oranları göz önüne alınmadan, sadece psikiyatrik hastalıklarından aldıkları engel oranları incelendiğinde; ortalamanın $\% 53,2 \pm 21,6$ olduğu saptandı. Olguların psikiyatrik engel oranlarının dağılımı Grafik 2'de gösterildi. Kişide birden fazla psikiyatrik hastalık söz konusu olduğunda, engel oranı Balthazard Formülüi ile hesapland.

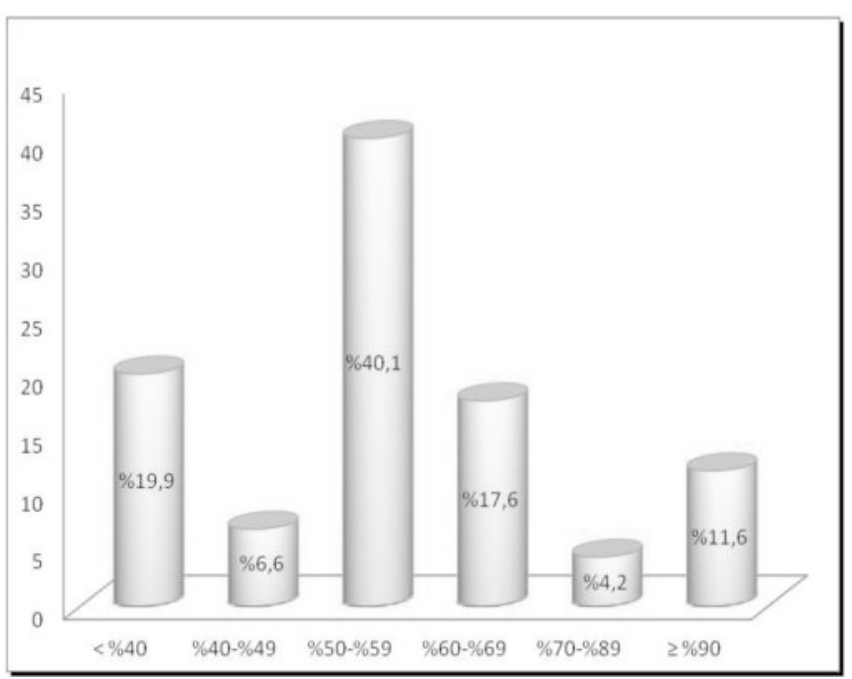

Grafik 2. Olguların psikiyatrik engel oranlarının dağılımı.

Raporlarda başvuru nedeni olarak özel eğitim alabilme isteği ( $n=2005$; \%95,3) ilk sıradaydı. Başvuru nedeni olarak birden fazla nedenin belirtilebildiği görüldü. Olguların engelli sağlık kurulu raporu istek nedenleri Tablo 3’te belirtildi.
Tabloda belirtilen yüzdeler çalışma kapsamında incelenen toplam rapor sayısına ( $\mathrm{n}=2103)$ oranlanarak hesaplandı.

Tablo 3. Olguların engelli sağlık kurulu raporu istek nedenleri.

\begin{tabular}{|l|c|c|}
\hline Rapor istek nedeni & Olgu sayısı & $\mathbf{\%}$ \\
\hline Özel eğitim & $\mathbf{2 0 0 5}$ & $\mathbf{9 5 , 3}$ \\
\hline Belediye hizmetleri & 748 & 35,6 \\
\hline Evde bakım parası alma & 659 & 31,3 \\
\hline 2022 sayılı yasa & 516 & 24,5 \\
\hline Vergi indirimi & 464 & 22,1 \\
\hline ÖTV muafiyeti & 406 & 19,3 \\
\hline Diğer* & 358 & 17,0 \\
\hline Ortopedik engele yönelik cihaz ** & 197 & 9,4 \\
\hline
\end{tabular}

*Diğer; fizik tedavi hizmeti alabilmek, refakatçi işlemleri, trafik sigortasına vermek, tedavi-ilaç-mama-alt bezi vs. giderleri, kamu kurum ve hastanelerinde öncelik tanınması, engelli kartı alma vs.

**Ortopedik engele yönelik cihaz; ortez-protez gibi yardımcı cihazlar, özel tertibatlı akülü araç ve tekerlekli sandalye.

Olguların özel eğitim alma isteğinin yaş gruplarına göre dağılımı incelendiğinde, en büyük oranı 5-9 yaş grubunun oluşturduğu $(\% 38,7)$ saptandı. Özel eğitim alma isteğinin yaş gruplarına göre dağ 11 ımı Grafik 3’te gösterildi.

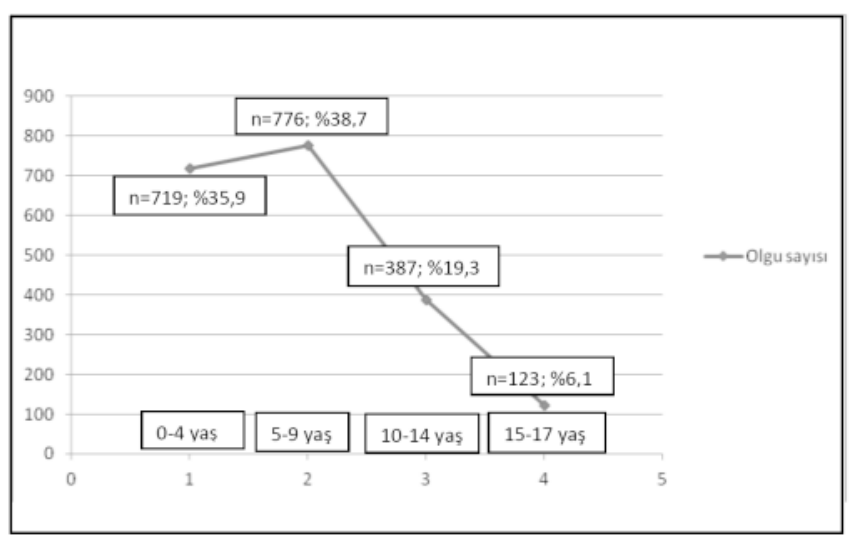

Grafik 3. Olguların özel eğitim alma isteğinin yaş gruplarına göre dağılımı.

\section{Tartışma ve Sonuç}

Tüm engelli çocuklar arasında psikiyatrik engeli bulunan çocuklar, üzerinde titizlikle durulması gereken bir grubu oluşturmaktadır. Bu çalışmada, engelli sağlık kurulu raporu almak için yapılan 18 yaş altı başvuruların 3/4’ünü psikiyatrik engeli bulunan çocukların oluşturması bu tespitimizi destekleyen bulgulardan biri olarak düşünülmüştür. Yapılan bir çalışmada (16), psikiyatrik engelli grubu içinde değerlendirilen zihinsel engellilerin pek çok toplumda gelişme olanağı bulamayan bir engelli grubunu oluşturduğu belirtilmekte ise de, son yillarda bu konuda yapilan çalışmaların arttığı, engelli çocuklarla ilgili yapılan çalışmaların başta genel engellilikle ilgili olmak üzere, özellikle zihinsel 
engelli çocuklarla ilgili olduğu görülmektedir (17-19).

Engelli çocuklar içinde özellikle psikiyatrik engeli bulunanların, bakımlarının zor olması, hareketli olmaları, diğer çocuklardan beklenen normal davranış özelliklerini gösterememeleri, kendilerine yönelik olumsuz davranış ve hareketlerden kaçınamamaları gibi sebeplerle normal bireylere nazaran ihmal ve istismar açısından daha fazla risk taşıdığı bilinmektedir. Engelli çocuklara karşı şiddet riski ve prevalansını konu olan bir çalışmada zihinsel engelli çocukların diğer tip engeli olan çocuklara göre daha yüksek oranda şiddete uğrama riskine sahip oldukları tespit edilmiştir (4). Yapılan bir başka çalışmada, çocuğa yönelik şiddetin bazen ölüme bile yol açabileceği belirlenmiş olup, filisid (çocuğun ailesi tarafından öldürülmesi) kurbanı olan engelli çocukların çoğunluğunun erkek ve otistik olduğundan söz edilmiştir (5).

Kötï muamele gören çocuklar ve engellilik ile ilgili bir çalışmada, engeli olmayan çocuklarda kız çocuklarının tüm istismar tiplerinde daha fazla mağduriyetlerinin söz konusu olduğu, engelli çocuklarda ise, engelli erkeklerin fiziksel istismara daha fazla maruz kaldıkları, engelli kızların da cinsel istismar açısından ön plana çıtı̆̆ğ belirtilmiştir (11). Bu çalışmada psikiyatrik engelli çocukların çoğunluğunu, erkek çocukların oluşturduğu saptandı. Engelli çocuklarla ilgili genel çalışmalarda da erkek oranının fazla olduğu görüldü $(6,14,17,18)$. Genel engelli çalışmalarında, erkek sayısının fazla olmasında zeka geriliği, otistik bozukluk, asperger bozukluğu gibi zihinsel hastalıkların rol oynadığı belirtilmektedir (20). Bu durum, psikiyatrik engelli çocukları kapsayan çalışmamızdaki erkek olgu sayısının fazlalığı ile uyumludur. Erkeklerin merkezi sinir sisteminin dış etmenlere karşı daha dayanıksız olması, erken doğum, X genine bağlı zeka geriliği gibi durumların erkeklerde daha sık görülmesi, erkek psikiyatrik engelli çocukların fazla görülmesinin sebepleri arasında sayılmaktadır (20). Engelli erkek çocuk sayısının fazla olmasının, fiziksel istismarın engelli erkeklerde daha fazla görülmesine sebep olabileceği düşünüldü.

Engelli sağlık kurulu raporu almak için başvuran ve psikiyatrik engeli bulunan olguların yaşlarına bakıldığında, yaş ortalamasının $6,7 \pm 4,3$ olduğu saptandı. Şahin ve ark.'nın çalışmasında ise, yaş ortalamasının $8,55 \pm 4,51$ olduğu görüldü (17). Şahin ve ark.'nın çalışmasında yaş ortalamasının daha büyük olması, psikiyatrik tanı dağılımının yanında diğer sistemleri ilgilendiren engel durumlarının da incelenmesi ile ilişkilendirilmiştir. Çalışmamızda, psikiyatrik engeli bulunan olguların yaş ortalamasının tüm engel durumunu kapsayan çalışmalara göre daha küçük olması, ailelerin psikiyatrik engelli çocukları konusunda daha hassas olduklarını ve çocukları için daha erken yaşta devletin sağladığı haklardan yararlanmak için başvurduklarını düşündürmüştür. Bu durum, istismar açısından da koruyucu bir faktör olarak görülmüş̧ür.

Engelli çocuklarla ilgili çalışmaların çoğunda hastalık tanıları incelendiğinde, genellikle zeka geriliklerinin önemli bir yer tuttuğu görülmektedir $(17,18,20)$. Bu çalışmada da en yüksek oranı ( $\mathrm{n}=911 ; \% 43)$ hafif zeka geriliği bulunan çocukların oluşturduğu saptandı. Çocuk ve ergenlerde engelli sağlık kuruluna başvuran hastaların psikiyatrik tanılarının incelendiği çalışma sayısı oldukça azdır ve yapılan çalışmalar çoğunlukla engellilik prevalansı üzerinedir (17). Engelli çocuklar ve kötü muamele ile ilgili bir çalışmada, mental retarde çocukların engelli olmayan çocuklara göre kötü muamelenin bütün tipleri açısından $4 \mathrm{kez}$ daha fazla risk taşıdığından ve engel tipi ile istismar tipi arasında istatistiksel olarak anlamlı bir ilişki bulunmadığından söz edilmektedir (11). Vural ve ark. tarafından yapılan bir çalışmada, cinsel istismar nedeniyle çocuk psikiyatrisi polikliniğine gönderilen olguların \%76,1'inde donuk düzey ile ağır zeka geriliği arasında değişik düzeylerde zihinsel gerilik saptandığı bildirilmiş olup, cinsel istismar açısından çocukta mental retardasyon varlığının istismar riskini arttırmış olabileceği belirtilmiştir (3). Soylu ve ark.'nın çalışmasında da, mental ve psikiyatrik bozukluğu bulunan çocuk ve adölesanların cinsel istismar açısından artmış bir risklerinin olduğundan bahsedilmiştir (2). Sullivian ve Knutson'un çalışmasında ise davranışsal bozukluğu ve zihinsel engeli olan çocukların duygusal istismara maruz kalmasının daha fazla olası olduğundan söz edilmiştir (11). Bu nedenle, psikiyatrik engelli çocukların tanı ve özelliklerini gösteren çalışmaların arttırılması, özellikle istismar açısından alınabilecek önlemler için önem taşımaktadır.

Çalışmamızda psikiyatrik hastalıklar nedeniyle verilen engel oranlarının büyük kısmının \%50-\%59 arasında olduğu saptandı. Bu sonuçların, ilgili yönetmeliğe göre $\% 50$ engel oranı verilen hafif zeka geriliği tanısının fazla olmasından kaynaklandığı düşünüldü.

Yapılan çalışmalarda, engelli raporu düzenlenmesi amacıyla Engelli Sağlık Kuruluna başvuru nedenleri arasında; belediye hizmetlerinden, vergi indiriminden, 2022 sayıl1 yasadan ve özel eğitimden yararlanmak, ÖTV (özel tüketim vergisi) muafiyeti, evde bakım ücreti almak gibi engellilere tanınan haklardan faydalanmak yer almaktadır (14,17-19). Psikiyatrik hastalıkları bulunan çocukları kapsayan bu çalışmada, özel eğitimden yararlanma isteği \%95,3 gibi yüksek bir oranla ilk sırada olup, engelli çocuklarla ilgili diğer çalışmalarda da özel eğitim isteğinin ilk sırada yer aldığ görülmektedir $(14,17)$. Bu durum, tanı olarak zeka geriliklerinin yüksek oranda olması ile ilişkilendirilmiştir. Aynı zamanda üniversitemiz çocuk psikiyatrisi polikliniğine tanı ve tedavi amacıyla başvuran ve özel eğitimden fayda göreceği düşünülen olgular, gerekli bilgilendirme ile birlikte engelli 
sağlık kuruluna yönlendirilmektedir. Bu durum, hem özel eğitim isteğinin, hem de tanı olarak zeka geriliklerinin başvurularda öne çıkmasının sebebi olarak düşünülmüştür. Şahin ve ark.'nın çalışmasında da, ailelerin özel eğitime ihtiyacı olan çocukları için doktor ya da öğretmen tarafından bilgilendirilmesi ve özel eğitim almaları için yönlendirilmesi durumunun özel eğitimden yararlanmak için başvurma oranının yüksek olmasına neden olabileceği belirtilmiştir (17).

Bu çalışmada \%4,6'llk bir oranda özel eğitim isteği bulunmaması durumu, Akar ve ark.'nın çalışmasındaki özel eğitim istenmeme oranının (\%8,3) yaklaşık yarısı kadardır (14). Çalışmamızda özel eğitim isteğinde bulunulmaması, bazı olguların özel eğitim ihtiyaçlarının olmaması, bazılarının özel eğitimden fayda göremeyecek durumda bulunması ve bazı olguların da sadece özel eğitimden faydalanmak için raporları bulunup, bunun dışındaki diğer haklardan yararlanabilmek için yeniden rapor talebinde bulunmaları ile ilişkilendirilmiştir. Akar ve ark. çalışmalarında tespit ettikleri özel eğitim istenmeme oranını ihmal olarak yorumlamıșlarsa da belirtilen sebeplerin de akılda bulundurulması gerektiği düşünülmüştür.

Çocuğun özel bir eğitime ihtiyacı olduğunun belki de ilk fark edildiği okul öncesi dönem ile ilkokul çağının ilk dönemlerini kapsayan 5-9 yaş arasında engelli sağlık kurulu raporu almak için başvuruların en yüksek oranda olduğu ve 10 yaşından itibaren özel eğitim isteğinin giderek azaldığ 1 görüldü. Cinsel istismara uğrayan çocuk ve ergenlerle yapılan bir çalışmada, olguların \%21,6'sının okula devam etmediği veya yaşına uygun bir eğitim almadığ etmeyen çocuklar için uygun bir eğitim planlanmasının, eğitim açısından zaman kaybı olan çocuklar için koruyucu önlemler alınmasının, istismarı önlemeye katkı sağlayabileceği bildirilmiştir (3). Engelli olsun ya da olmasın çocukların eğitimine önem verilmesinin istismarı önleyici adımlardan biri olduğu düşünülmektedir. Engelli çocukların erken yaşta aldıkları eğitim yemek yeme, giyinme, iletişim, tuvalet ve yıkanma gibi temel ihtiyaçlarıla ilgili becerileri kazanmalarına ve yetişkinlikte ihtiyaç duyacakları desteğin azalmasına da sebep olacağından (14), istismar açısından diğer çocuklara göre daha riskli bir grupta bulunan engelli çocukların eğitimi üzerinde daha fazla durulması gerektiği kanısındayız.

Sonuç olarak, engelli bir çocukla karşılaşan hekimlerin ve diğer sağlık personelinin, özellikle de zihinsel engelli çocukların tedavisini üstlenen çocuk psikiyatrisi alanında çalışan hekimlerin, ihtiyacı olan hastalarını eğitim ve diğer sosyal haklardan faydalanabilmeleri için yönlendirmeleri gereklidir $(17,19)$. Psikiyatrik engelli çocukların yararlanabileceği en önemli sosyal haklardan biri olan özel eğitim hakkı, engelli raporu ile ücretsiz olarak sunulmaktadır. Devletin bu hakkı ücretsiz olarak ihtiyaç sahiplerine tanıması, çocuğun istismardan korunmasında önemli bir adımdır. Engelli sağllk kurulu raporu başvuru nedenleri arasında ilk sırada özel eğitimin yer alması, ailelerin -bilinçli ya da değilçocuğu istismardan korumaya katkıda bulunduğunu göstermektedir.

\section{Kaynaklar}

1. Mikton C, Maguire H, Shakespeare T. A systematic review of the effectiveness of interventions to prevent and respond to violence against persons with disabilities. J Interpers Violence 2014;29(17):3207-26 doi: 10.1177/0886260514534530. Pubmed PMID:24870959.

2. Soylu N, Alpaslan AH, Ayaz M, Esenyel S, Oruç M. Psychiatric disorders and characteristics of abuse in sexually abused children and adolescents with and without intellectual disabilities. Res Dev Disabil 2013;34:4334-42. doi: 10.1016/j.ridd.2013.09.010. Pubmed PMID: 24161460.

3. Vural P, Uçar HN, Eray Ş, Çolpan M, Kocael Ö. Uludağ Üniversitesi Tıp Fakültesi Hastanesi Çocuk Psikiyatrisi polikliniğine yönlendirilen adli olguların sosyodemografik ve klinik özelliklerinin değerlendirilmesi. Uludağ Üniversitesi Tıp Fakültesi Dergisi 2013;39(1):49-53.

4. Jones L, Bellis MA, Wood S, Hughes K, McCoy E, Eckley L, Bates G, Mikton C, Shakespeare T, Officer A. Prevalance and risk of violence against children with disabilities: a systematic review and meta-analysis of observational studies. Lancet 2012;380:899-907. doi: 10.1016/S0140-6736(12)60692-8. Pubmed PMID: 22795511.

5. Coorg R, Tournay A. Filicid-suicide involving children with disabilities. J Child Neurol 2012;28(6):745-51. doi: 10.1177/0883073812451777. Pubmed PMID: 22826515.

6. Turner HA, Vanderminden J, Finkelhor D, Hamby S, Shattuck A. Disability and victimization in a national sample of children and youth. Child Maltreat 2011;16(4):275-86. doi: 10.1177/1077559 511427178. Pubmed PMID: 22114182.

7. Manders CE, Stoneman Z. Children with disabilities in the child protective services system: An analog study of investigation and case management. Child Abuse Negl 2009;33:229-37. doi: 10.1016/j.chiabu.2008.10.001. Pubmed PMID: 19348941.

8. Sullivan PM. Violence exposure among children with disabilities. Clin Child Fam Psychol Rev 2009;12:196-216. doi: 10.1007/s10567009-0056-1. Pubmed PMID: 19517229.

9. Govindshenoy M, Spencer N. Abuse of the disabled child: a systematic review of population-based studies. Child Care Health Dev. 2007;33(5):552-8. Pubmed PMID: 17725777.

10. Deveci SE, Açık Y. Çocuk istismarı nedenlerinin incelenmesi. Arşiv Kaynak Tarama Dergisi 2003;12(4):396-405.

11. Sullivan PM, Knutson JF. Maltreatment and disabilities: a population-based epidemiological study. Child Abuse Negl 2000;24(10):1257-73. Pubmed PMID: 11075694.

12. 65 Yaşını Doldurmuş Muhtaç, Güçsüz Ve Kimsesiz Türk Vatandaşlarına Aylık Bağlanması Hakkında Kanun. 10.07.1976 tarihli 15642 sayıl Resmi Gazete, Ankara. (http://www.mevzuat .gov.tr/MevzuatMetin/1.5.2022.pdf). [Erişim Tarihi 06.01.2015].

13. Engelliler Hakkında Kanun. 07.07.2005 tarihli 25868 sayılı Resmi Gazete, Ankara. (http://www.mevzuat.gov.tr/ MevzuatMetin/ 1.5.5378.pdf). [Erişim Tarihi: 15.09.2014].

14. Akar T, Değirmenci B, Demirel B. Gözden kaçan bir çocuk ihmali alanı: özürlü çocuklarda özel eğitim. Turkiye Klinikleri J Foren Med 2011;8(2):66-71.

15. Aile ve Sosyal Politikalar Bakanlığı, Çalışma ve Sosyal Güvenlik 
Bakanlığı, Maliye Bakanlığı, Millî Eğitim Bakanlığı ve Sağlık Bakanlığından: Özürlülük Ölçütü, Sınıflandırması ve Özürlülere Verilecek Sağlık Kurulu Raporları Hakkında Yönetmelik. 30.03.2013 tarihli 28603 say1l Resmi Gazete, Ankara. (http://www.resmigazete.gov.tr/eskiler /2013/03/201303304.htm). [Erişim Tarihi: 15.09.2014].

16. Salman F, Engellilere yönelik ayrımcılık, Ed: Aktan İ, Hep yenik başlama duygusu. Türkiye'de ayrımcılık uygulamaları: Mağdurlar ve uzmanlar anlatıyor, Genişletilmiş 2. Baskı, Ankara, Odak Ofset Matbaacilık, 2007:45-56.

17. Şahin N, Altun H, Kara B. Özürlü Çocuk Sağlık Kurulu raporlarının değerlendirilmesi. Kocatepe Tıp Dergisi 2014;15(1):48-53.
18. Başgül ŞS, Saltık S. Göztepe Eğitim ve Araştırma Hastanesi-Özürlü Çocuk Heyeti'nin 2010 yılı verileri. Göztepe Tip Dergisi 2012;27 (2):45-9. doi:10.5222/J.GOZTEPETRH.2012.045.

19. Özbaran B, Köse S. Çocuk Psikiyatrisi pratiğinde özürlü sağlık kurulu raporları: 6 yıllık Ege Üniversitesi deneyimi. Çocuk ve Gençlik Ruh Sağllğ̆ Dergisi 2011;18(1):67-72.

20. Doğangün B. Özel eğitim gerektiren psikiyatrik durumlar. İ.Ü. Cerrahpaşa Tıp Fakültesi Sürekli Tıp Eğitimi Etkinlikleri. Türkiye'de Sık Karşılaşılan Psikiyatrik Hastalıklar Sempozyum dizisi. 2008;62:157-74. 